\title{
Magdalena SzUbielska
}

Katolicki Uniwersytet Lubelski Jana Pawła II Instytut Psychologii, Katedra Psychologii Eksperymentalnej

20-950 Lublin, Al. Racławickie 14

e-mail:magdasz@kul.pl

\section{BogustaW MareK}

Katolicki Uniwersytet Lubelski Jana Pawła II

Instytut Filologii Angielskiej

Katedra Tyflodydaktyki Języka Angielskiego

i Komunikacji Alternatywnej

20-950 Lublin, Al. Racławickie 14

e-mail: bmarek@kul.pl

\section{ROLA DOŚWIADCZENIA WZROKOWEGO W PROCESIE MAJORYZACJI I MINORYZACJI WYOBRAŻENIOWEJ RAPORT Z BADAŃ UCZNIÓW NIEWIDZĄCYCH*}

\begin{abstract}
Abstrakt. Wiadomo, że możliwość wizualizacji wyobrażeń, związana z posiadaniem wspomnień wzrokowych, pomaga osobom niewidzącym w wykonywaniu wielu zadań, w które zaangażowana jest wyobraźnia przestrzenna. W dwóch eksperymentach z udziałem uczniów niewidzących sprawdzano, jakie znaczenie ma możliwość wizualizacji wyobrażeń dla zdolności wykonywania operacji zmiany wielkości obiektów w wyobraźni. Zgodnie z hipotezami niewidomi od urodzenia (H1) popełniają większy błąd powiększając w wyobraźni obiekty (eksperyment 1: majoryzacja wyobrażeniowa) oraz (H2) w mniejszym stopniu pomniejszają oddalający się w wyobraźni przedmiot (eksperyment 2: minoryzacja wyobrażeniowa), niż uczniowie niewidzący posiadający wspomnienia wzrokowe. Hipoteza pierwsza została częściowo potwierdzona. Uczniowie niewidomi od urodzenia wykazywali tendencję do większego przeszacowywania wysokości powiększonych w wyobraźni, dotykanych uprzednio przedmiotów, niż uczniowie niewidzący posiadający wspomnienia wzrokowe. Hipoteza druga nie uzyskała poparcia empirycznego - obydwie badane grupy w porównywalnym stopniu pomniejszały w wyobraźni oddalający się od nich przedmiot.
\end{abstract}

Słowa kluczowe: majoryzacja wyobrażeniowa, minoryzacja wyobrażeniowa, niewidzący uczniowie, wizualizacja, wyobraźnia przestrzenna.

${ }^{*}$ Badania prezentowane w artykule finansowane były przez Ministerstwo Nauki i Szkolnictwa Wyższego w ramach grantu nr N N106 279339, dotyczącego funkcjonowania w zakresie percepcji dotykowej, wyobraźni przestrzennej i interpretacji grafiki dotykowej przez uczniów z poważną dysfunkcją wzroku. Dziękujemy Pani Aldonie Kalkus za pomoc w organizacji i przeprowadzeniu badań. 


\section{WPROWADZENIE}

Majoryzację i minoryzację można zaliczyć do grupy operacji wyobrażeniowych, czyli manipulacji na wyobrażeniach. Majoryzacja definiowana jest jako „W miarę równomierne powiększanie całego obrazu [...]; przypomina efekt użycia lupy, a dokładniej - transfokatora" (Młodkowski, 1998, s. 255). Przez analogię minoryzację możemy określić jako zabieg polegający na proporcjonalnym pomniejszaniu wyobrażonego obiektu.

Operacje umysłowej zmiany wielkości obiektów są przedmiotem eksperymentów o wiele rzadziej, niż cieszące się wśród badaczy popularnością operacje skaningu czy rotacji. Niemniej jednak można znaleźć badania dotyczące pomniejszania bądź powiększania wyobrażeniowego obiektów, prowadzone zarówno w grupie osób widzących, jak i niewidomych (Arditi i in., 1988; Kennedy, 1993; Szubielska, 2009; 2013; Vanlierde, Wanet-Defalque, 2005). Wydawać by się mogło, że trafne przeprowadzenie tych operacji w umyśle zależy od doświadczeń wzrokowych bardziej niż inne procesy wyobrażeniowe. Osoby widzące na co dzień po wielokroć doświadczają w percepcji wzrokowej powiększania (np. obserwując nadjeżdżający samochód) bądź pomniejszania obiektów (np. patrząc na odlatujący samolot), które dzięki posiadaniu niezmienników percepcyjnych traktują jako tożsame. Ponadto często obserwują pracę transfokatora, np. korzystając $\mathrm{z}$ aparatów fotograficznych, a jeszcze częściej - podczas oglądania programów telewizyjnych czy filmów (tzw. zoom, czyli przybliżanie albo oddalanie sceny, stanowi jeden z powszechnie stosowanych zabiegów montażowych, zob. np. Młodkowski, 1998). Co ciekawe, osobom całkowicie pozbawionym tego typu doświadczeń proces majoryzacji umysłowej nie sprawia większego problemu niż skaning i rotacja wyobrażeniowa. Szubielska (2013) prowadziła badania, w których niewidomi od urodzenia dorośli ze zbliżoną trafnością i w porównywalnym czasie rozwiązywali zadania dotykowego porównywania kształtów figur: (1) pozostających względem siebie w tej samej pozycji; (2) obróconych o $90^{\circ}$ oraz (3) powiększonych względem wzorca. Skąd osoby pozbawione doświadczeń wzrokowych czerpią wiedzę o majoryzacji/minoryzacji? Być może wystarczyła im zabawa $\mathrm{z}$ nadmuchiwaniem i spuszczaniem powietrza $\mathrm{z}$ balonu, albo wiedza na temat magicznych właściwości niektórych obiektów, zdobyta np. podczas lektury Alicji w Krainie Czarów (tytułowa bohaterka po zjedzeniu czarodziejskiego ciastka czy wypiciu napoju rosła bądź zmniejszała się proporcjonalnie).

Z wielu badań wynika, że doświadczenie wzrokowe oraz związana z nim tendencja do wizualizacji wyobrażanych obiektów i scen (Vanlierde, Wanet-Defalque, 2004) ułatwia sprawne przeprowadzenie operacji na wyobrażeniach (zob. np. przegląd badań: Cattaneo $\mathrm{i}$ in., 2008). Ograniczenia w funkcjonowaniu procesów wyobrażeniowych są więc charakterystyczne zwłaszcza dla osób niewidomych od urodzenia oraz takich, które straciły wzrok do około trzeciego roku życia (czyli w okresie, który obejmuje amnezja dziecięca, zob. np. Jagodzińska, 2003; 
W związku z tym można uznać, że osoby te nie posiadają wspomnień w kodzie wzrokowym). Ograniczenia te dotyczą m.in. skaningu oraz rotacji umysłowej. Toroj i Szubielska (2011) stwierdziły, że dorosłe osoby późno niewidome (late blind) (badano osoby, który przestały widzieć między 8. a 25. rokiem życia) trafniej niż niewidomi od urodzenia wykonywały operację skaningu w zadaniu polegającym na porównywaniu kształtów dotykanych par obiektów. Marmor i Zaback (1976), prowadząc eksperyment nad rotacją wyobrażeniową, zaobserwowali, iż grupa osób nieposiadających wspomnień wzrokowych (niewidomi od urodzenia oraz tzw. wcześnie niewidomi - early blind) wykonywała zadania dotykowego porównywania obróconych względem siebie kształtów wolniej i mniej trafnie niż grupa osób, które późno straciły wzrok oraz widzących, którym na czas trwania eksperymentu zasłonięto oczy. Z kolei w badaniach porównawczych osób niewidomych od urodzenia i widzących, dotyczących majoryzacji wyobrażeniowej (Szubielska, 2009), nie stwierdzono istotnych różnic $\mathrm{w}$ trafności wykonywania zadań ze względu na posiadane doświadczenie wzrokowe. Jednak warto dodać, iż zadania wymagały percepcji dotykowej złożonych bodźców przedstawionych w postaci rysunków wypukłych i widzący wykonywali je z zasłoniętymi oczami. Zatem badane grupy różniła nie tylko możliwość wizualizacji wyobrażeń, ale i zakres doświadczeń w zakresie eksploracji dotykowej obiektów. Pierwsza ze zmiennych różnicujących grupy mogła wpływać korzystnie na wyniki osób widzących, zaś druga - działała na ich niekorzyść (zob. np. Heller, 2006; Heller i in., 2002).

Wykonano również badania, w których pokazano ograniczenia procesu minoryzacji wyobrażeniowej u osób pozbawionych wspomnień wzrokowych. Arditi i współpracownicy (1988) przeprowadzili eksperyment, w którym prosili o wyobrażenie sobie obiektów na trzech różnych (rosnących) dystansach i ocenę ich wielkości poprzez wskazanie rękami lewej i prawej krawędzi wyobrażonego przedmiotu. Badacze stwierdzili, że niewidomi od urodzenia dorośli nie pomniejszali w wyobraźni oddalających się obiektów. Z wypowiedzi osób badanych wynikało, że nie rozumieją oni zadania wyobrażania sobie wielkości oddalających się obiektów. Badani mówili na przykład, że wyobrażenie jest zawsze takie samo, niezależnie od dystansu. Zdarzało się, że uznawali nawet, iż oddalający się przedmiot powiększa się, ponieważ trzeba dalej po niego sięgać. Vanlierde i Wanet-Defalque (2005) stwierdziły, że osoby dorosłe, które utraciły wzrok we wczesnym dzieciństwie, także nie rozumieją zasad perspektywy, a konkretnie tego, że oddalające się od obserwatora obiekty są widziane jako mniejsze. $40 \%$ badanych stwierdziło, że zadanie oceny wielkości przedmiotów na różnych dystansach nie ma sensu, ponieważ obiekt ma zawsze ten sam rozmiar. Natomiast zarówno osoby widzące, jak i ociemniałe pomniejszały w wyobraźni obiekty, które oddalały się od nich. Wydaje się, że o trafniejszym wykonaniu zadania przez osoby ociemniałe niż osoby nieposiadające wspomnień wzrokowych ponownie zadecydowała możliwość wizualizacji oddalającego się obiektu, jak i pamięć o tym, w jaki sposób zmienia się wygląd obiektów obserwowanych z różnych punktów widzenia. 
Co ciekawe, badania Kennedy'ego (1993) prowadzone w dwóch grupach dzieci i młodzieży niewidzącej wykazały, że badani rozumieli, iż wraz ze wzrostem dystansu obiekty wydają się zmniejszać swój rozmiar - oddalając się od ściany oceniali, że jej krawędzie leżą coraz bliżej siebie. W pierwszej z badanych grup znalazły się dzieci mieszkające na Haiti, w wieku 9-18 lat, posiadające pewne doświadczenie wzrokowe (średni wiek utraty wzroku wynosił 8,5 roku). Druga grupa obejmowała niewidome od urodzenia dzieci amerykańskie w wieku od 5 do 14 lat. Niestety, autor nie porównał, która z grup w większym stopniu pomniejszała rozmiar znajdującej się coraz dalej od obserwatora ściany.

W celu sprawdzenia, jakie znaczenie ma doświadczenie wzrokowe i związana z nim możliwość wizualizacji wyobrażeń dla trafności wykonywania operacji majoryzacji wyobrażeniowej, postanowiono zbadać uczniów niewidzących, różniących się ze względu na posiadanie wspomnień wzrokowych. Wybierając tę grupę badawczą, kontrolowano dodatkowo zmienną, jaką jest doświadczenie dotykowe (zdolności w zakresie percepcji manualnej i wykonywania zadań wyobrażeniowych korelują ze sobą: Szubielska, Marek, 2012) - wszyscy uczniowie uczęszczali na zajęcia, podczas których doskonalili percepcję haptyczną.

Postawiono hipotezę, iż: (H1) uczniowie niewidomi od urodzenia, ze względu na brak możliwości wizualizacji wyobrażeń, powiększając w wyobraźni przedmiot, którego uprzednio dotykali, popełniają większy błąd w ocenie jego wielkości, niż uczniowie niewidzący posiadający wspomnienia wzrokowe. W badaniu własnym postanowiono też sprawdzić, w jaki sposób doświadczenie wzrokowe niewidzących dzieci i młodzieży różnicuje wykonywanie zadania oceny wielkości oddalających się obiektów.

Postawiono hipotezę, zgodnie z którą: (H2) uczniowie niewidomi od urodzenia, w porównaniu z niewidzącymi rówieśnikami posiadającymi wspomnienia wzrokowe, w mniejszym stopniu pomniejszają oddalający się w wyobraźni przedmiot.

\section{METODA}

\subsection{Osoby badane}

Zbadano 19 wychowanków (6 uczniów, 13 uczennic) ośrodków szkolno-wychowawczych dla dzieci niewidomych i słabowidzących w Lublinie oraz w Łodzi. Wiek badanych wahał się od 6 do 18 lat. Badani różnili się doświadczeniem wzrokowym - zbadano grupę uczniów: (1) niewidomych od urodzenia oraz (2) uczniów, którzy stracili wzrok w okresie średniego lub późnego dzieciństwa i deklarowali wspomnienia wzrokowe. W pierwszej grupie znajdowało się 11 uczniów (4 płci męskiej; średnia wieku wynosiła 12 lat i 9 miesięcy, 
$S D=3$ lata), w drugiej 8 uczniów (2 płci męskiej; średnia wieku wynosiła 15 lat i 1 miesiąc, $S D=2$ lata i 2 miesiące). Wszyscy badani mieli co najwyżej poczucie światła. Ponadto z racji uczęszczania do szkoły o specjalnym charakterze posiadali oni pewne doświadczenia w zakresie korzystania z grafiki dotykowej.

\subsection{Materiały badawcze}

Do badań wykorzystano figurki z klocków LEGO Duplo: żyrafę ( $6,5 \mathrm{~cm}$ szerokości i $10 \mathrm{~cm}$ wysokości) oraz psa (5 cm szerokości i 4,5 cm wysokości), a także sznurek (do szacowania wielkości wyobrażonych obiektów przez badanych) i centymetr (do mierzenia oszacowanej wielkości przez eksperymentatora).

\subsection{Procedura}

Badani brali udział kolejno w dwóch eksperymentach (stanowiły one część większego projektu badawczego). Pierwszy dotyczył majoryzacji wyobrażeniowej, a drugi - minoryzacji wyobrażeniowej. Badania prowadzono indywidualnie, w wyciszonym pomieszczeniu na terenie szkoły.

Zmienną niezależną w obydwu eksperymentach stanowiło doświadczenie wzrokowe uczniów niewidzących (doświadczenia wzrokowego nie posiadali uczniowie niewidomi od urodzenia, posiadali je zaś uczniowie ociemniali, którzy stracili wzrok w okresie średniego lub późnego dzieciństwa).

W eksperymencie pierwszym badani dotykali przez dowolny czas pojedynczej figurki, dla kolejnych zadań: żyrafy oraz psa. Następnie odkładali figurkę i mieli powiększyć ją proporcjonalnie w wyobraźni (mówiono: „wyobraź sobie, że figurka rośnie jak balon”). Żyrafę badani mieli powiększyć w wyobraźni czterokrotnie, a psa - siedmiokrotnie. Następnie za pomocą sznurka trzymanego w dwóch rękach badani określali wielkość powiększonej figurki na podanym wymiarze - oceniano wysokość żyrafy i długość psa. Zmienną zależną była wielkość błędu w szacowaniu, wyrażona jako różnica między wielkością określoną przez ucznia a rzeczywistą wielkością powiększonej figurki.

Zadanie minoryzacji, które wykonywano w eksperymencie drugim, polegało na ocenie wielkości oddalającego się w wyobraźni obiektu (podobnie jak zadania, które stosowali Arditi, Holtzman i Kosslyn, 1988 oraz Vanlierde i Wanet-Defalque, 2005). Badani mieli wyobrazić sobie łyżkę do zupy, która znajduje się w trzech różnych miejscach: (1) na ich kolanach; (2) na kolanach osoby, która siedzi w odległości 10 kroków od nich; (3) na kolanach osoby, która siedzi w odległości 20 kroków od nich. Każdorazowo zadawano pytanie, jakiej długości jest wyobrażona łyżka. Badani szacowali tę wielkość rękami, za pomocą trzymanego w nich sznurka. Oszacowaną długość zapisywano w centymetrach. 


\section{WYNIKI}

Wszystkie analizy wykonano w programie SPSS. Z uwagi na małą liczebność badanych grup zastosowano testy nieparametryczne, a także nie prowadzono analiz uwzględniających zróżnicowanie ze względu na wiek i płeć badanych uczniów. Dane z obydwu eksperymentów analizowano z wykorzystaniem testu U Manna-Whitneya, a dane z drugiego eksperymentu dodatkowo z wykorzystaniem testu Friedmana. Wyboru metod analizy danych dokonano na podstawie literatury przedmiotu (Brzeziński, 1996; Francuz, Mackiewicz, 2005).

\subsection{Wyniki eksperymentu 1 - majoryzacja wyobrażeniowa}

W grupie uczniów niewidomych od urodzenia błąd w szacowaniu wielkości figurki żyrafy wynosił średnio $19,00 \mathrm{~cm}(S D=13,91$; minimum $=-4,00$; maksimum $=40,00)$, a dla figurki psa 22,05 $\mathrm{cm}(S D=28,78$; minimum $=-11,50$; maksimum $=80,50)$. W grupie uczniów niewidzących, którzy mieli doświadczenie wzrokowe, średnia błędu szacowania wynosiła odpowiednio dla figurki żyrafy: $7,75 \mathrm{~cm}(S D=15,95$; minimum $=-8,00$; maksimum $=40,00)$ i psa: $7,35 \mathrm{~cm}$ $(S D=12,36 ;$ minimum $=-13,50 ;$ maksimum $=22,50)$.

Szacując wielkość powiększonej żyrafy, uczniowie niewidomi od urodzenia popełniali większy błąd (średnia ranga: 12,14) niż uczniowie niewidzący posiadający wspomnienia wzrokowe (średnia ranga: 7,06; wynik na granicy istotności statystycznej: $U=20,50 ; p=0,051)$. Wielkość błędu w ocenie wielkości powiększonego psa nie różniła się istotnie w obydwu badanych grupach $(U=34,50$; $p=0,442)$.

\subsection{Wyniki eksperymentu 2 - minoryzacja wyobrażeniowa}

Ocena wielkości łyżki w trzech kolejnych położeniach wynosiła odpowiednio w grupie uczniów niewidomych od urodzenia: $24,09 \mathrm{~cm}(S D=20,65$; minimum $=15,00$; maksimum $=86,00), 22,00 \mathrm{~cm}(S D=16,31$; minimum $=9,00$; maksimum $=65,00)$ i $21,82 \mathrm{~cm}(S D=22,90 ;$ minimum $=5,00$; maksimum $=$ $68,00)$; zaś w grupie uczniów niewidzących posiadających wspomnienia wzrokowe: $22,00 \mathrm{~cm}(S D=5,66$; minimum $=12,00$; maksimum $=30,00), 17,38 \mathrm{~cm}$ $(S D=6,19$; minimum $=9,00$; maksimum $=26,00)$ i $16,00 \mathrm{~cm}(S D=14,38$; minimum $=5,00 ;$ maksimum $=50,00$ ).

Porównania różnicy w ocenie wielkości łyżki w pozycji końcowej i początkowej w dwóch badanych grupach wykazały, że niewidomi od urodzenia (średnia ranga $=10,09$ ) oraz niewidzący posiadający wspomnienia wzrokowe (średnia ranga $=9,88)$ pomniejszają łyżkę $\mathrm{w}$ takim samym stopniu $(U=43,00 ; p=0,968)$. 
Test Friedmana wykazał ponadto, że zarówno grupa uczniów bez doświadczeń wzrokowych $\left(\chi^{2}(2)=6,33 ; p=0,042 ;\right.$ kolejne średnie rangi: 2,$\left.55 ; 1,95 ; 1,50\right)$, jak i z doświadczeniami wzrokowymi $\left(\chi^{2}(2)=9,00 ; p=0,011\right.$; kolejne średnie rangi: 2,$75 ; 2,00 ; 1,25)$ długość znajdującej się coraz dalej łyżki szacuje jako coraz mniejszą.

\section{DYSKUSJA WYNIKÓW}

Hipoteza 1, weryfikowana w eksperymencie pierwszym, została częściowo potwierdzona. Grupę uczniów niewidomych od urodzenia charakteryzowała tendencja do popełniania większego błędu w ocenie wielkości powiększonej figurki żyrafy niż uczniów niewidzących posiadających doświadczenie wzrokowe. Nie stwierdzono zaś różnic w ocenie długości powiększonej figurki psa - ale w tym przypadku w obydwu badanych grupach stwierdzono duże odchylenia standardowe otrzymanych wyników, co mogło utrudnić ujawnienie istotnych różnic między grupami (statystyki opisowe sugerują różnice zgodne z hipotezą 1). Otrzymane wyniki potwierdzają wynikający z licznych badań wniosek, iż doświadczenie wzrokowe ułatwia osobom niewidzącym efektywne wykonywanie zadań wyobrażeniowych (zob. Cattaneo i in., 2008).

Co interesujące, obydwie badane grupy miały tendencję do przeszacowywania wielkości powiększonego w wyobraźni przedmiotu, co widoczne jest na poziomie statystyk opisowych. Wiadomo, że dorosłe osoby niewidome tworzą trafniejsze dotykowe reprezentacje wielkości obiektów codziennego użytku niż widzący (Smith i in., 2005). W związku z tym w kolejnych badaniach warto byłoby rozstrzygnąć, czy otrzymany w naszym eksperymencie efekt przeszacowywania wynika $z$ nieumiejętności trafnej oceny wielkości obiektu przez uczniów niewidzących, która to umiejętność w późniejszym wieku może podlegać zmianom rozwojowym, czy też z trudności w powiększeniu obiektu w zadanej skali. Zagadnienie zdolności majoryzacji umysłowej przez osoby niewidzące wymaga dalszej empirycznej eksploracji również z uwagi na ograniczenia prezentowanego w artykule badania. Zastosowano w nim małą liczbę itemów, co było konsekwencją faktu, iż stanowił on część dużego projektu (zob. przyp. 1), który obejmował serię wielu badań. Kolejne eksperymenty nad majoryzacją powinny uwzględniać większą liczę zadań, dzięki czemu możliwa będzie manipulacja bądź kontrola wielu zmiennych, w tym: ocenianego wymiaru wielkości (długość, wysokość), przyjętej skali majoryzacji (powiększenie o 2, 3, 4 bądź większą ilość razy, a także sytuacja kontrolna oceny wielkości w skali 1:1), rodzaju powiększanych obiektów (semantyczne - w tym obiekty codziennego użytku w naturalnej wielkości i modele, np. figurki zwierząt; asemantyczne, np. klocki o różnych kształtach).

Hipoteza 2, weryfikowana w eksperymencie drugim, nie została potwierdzona. W obydwu grupach istotnie pomniejszano oddalającą się w wyobraźni łyżkę 
- co jest zgodne z wynikami badań Kennedy'ego (1993). Rezultat ten jednocześnie przeczy wnioskom, do których doszli Arditi i in. (1998) oraz Vanlierde i Wanet-Defalque (2005), iż doświadczenie wzrokowe jest konieczne, by dokonywać minoryzacji wyobrażeniowej oddalających się obiektów. O tym, że nie jest ono konieczne, przekonują nie tylko nasze badania oraz wyniki, które otrzymał Kennedy (1993), ale i rysunki niektórych osób niewidomych. Kennedy i Juricevic (2006) szczegółowo wyjaśniają, w jaki sposób, na bazie percepcji manualnej, osoby niekorzystające nigdy z modalności wzrokowej mogą w pewnym stopniu nabyć i zrozumieć zasady perspektywy. Podają też przypadek Tracy, dorosłej kobiety, która nigdy dobrze nie widziała, a całkowicie straciła wzrok w wieku dwóch lat (zob. też: Kennedy, Juricevic, 2003). Kobieta ta od dzieciństwa dużo rysowała i lubiła tę aktywność. Tworząc rysunki dotykowe, uwzględniała ona zasady obowiązujące w percepcji wzrokowej, np. rysując trzy rzędy szklanek stosowała perspektywę zbieżną (coraz bardziej odległe szklanki przedstawiła jako coraz mniejsze, a szklanki stojące w odleglejszych rzędach narysowała jako położone bliżej siebie). Niemniej jednak przypadek Tracy jest dość nietypowy.

Różnice w otrzymanych wynikach badań (Arditi i in., 1998 oraz Vanlierde, Wanet-Defalque, 2005 vs. Kennedy, 1993 oraz opisane w artykule badanie własne) można wyjaśnić dzięki analizie przyjętej w nich procedury eksperymentalnej. W dwóch pierwszych przytoczonych eksperymentach pomiar wielkości odbywał się w ten sposób, że badani kładli palce wskazujące na znajdującej się przed nimi kartce (Arditi i in., 1998) bądź linijce (Vanlierde, Wanet-Defalque, 2005). Wymagało to od badanych wykonywania równolegle dwóch zadań - wyobrażania sobie obiektu na określonym dystansie, a także szacowania jego wielkości rękami, które musiały być utrzymywane w stałej odległości od ciała, dość blisko niego. Podczas ustalania wielkości obiektów osoby niewidome cechuje preferencja do stosowania strategii wyobrażania sobie tego, że trzymają je w dłoniach (Smith i in., 2005). Wobec tego, stosując tę strategię i nie mogąc wyciągać przed siebie rąk, tak jakby sięgali po znajdujący się w oddali przedmiot, w kolejnych pomiarach badani szacowali jego wielkość jako niezmienioną. Natomiast zarówno w naszym badaniu, jak i tych prowadzonych przez Kennedy'ego (1993) badani, szacując wielkość, mogli robić to trzymając ręce w dowolnej odległości od ciała. Wyciągając ręce przed siebie, żeby chwycić znajdujący się w pewnej odległości obiekt, automatycznie zmniejszamy kąt między rękami (zob. Kennedy, 1993). Tym samym, chcąc określić wielkość obiektów znajdujących się coraz dalej od nich, uczniowie wyciągając ręce, zmniejszali jednocześnie szacowaną wielkość tych obiektów. Nie jest to jednoznaczne z tym, że również zmniejszali w wyobraźni oddalający się obiekt (niestety, nie pytano o to, co w wyobraźni dzieje się z oddalającym się obiektem). Zagadnienie minoryzacji wyobrażeniowej wymaga zatem dalszych studiów, np. uzupełnienia szacunków dokonywanych rękami estymacją obiektywnych miar wielkości (ocena w centymetrach).

Wspomniane rozbieżności w wynikach badań mogą być także spowodowane zróżnicowanym doświadczeniem w zakresie odbioru grafiki dotykowej, którym 
charakteryzowali się badani. U osób niewidomych stwierdzono dodatnią korelację między eksperckością w korzystaniu z grafiki dotykowej a trafnością wykonywania zadań wymagających wykorzystania wyobraźni przestrzennej (Dulin, Hatwell, 2006; Szubielska, Marek, 2012). Część dzieci i młodzieży, którą badał Kennedy (1993) - uczniowie amerykańscy - posiadała spore doświadczenie $\mathrm{w}$ zakresie odbioru oraz wytwarzania grafiki dotykowej. Badani przez nas uczniowie również takie doświadczenie posiadali. Niestety, ani Arditi i in. (1998), ani Vanlierde i Wanet-Defalque (2005), opisując grupę osób badanych, nie podają żadnych informacji na temat ich doświadczeń w korzystaniu z grafiki dotykowej.

$\mathrm{Na}$ zakończenie warto dodać, że przedstawione badania mają charakter wstępnej eksploracji podjętych zagadnień i są warte rozwijania w kolejnych eksperymentach. Niewątpliwie za ich ograniczenie należy uznać małe próby badawcze. Aczkolwiek, po pierwsze, zbadano wszystkich chętnych do udziału w projekcie uczniów z dwóch dużych ośrodków dla dzieci niewidomych i słabowidzących w Polsce, których rodzice wyrazili na to zgodę; po drugie, grupy o podobnej liczebności są dopuszczalne w przypadku tak nielicznej, a zarazem trudno dostępnej populacji badanych (np. Arditi i in., 1998; Kennedy, 1993; Vanlierde, Wanet-Defalque, 2005).

\section{BIBLIOGRAFIA}

Arditi A., Holtzman J. D., Kosslyn S. M. (1988). Mental imagery and sensory experience in congenital blindness. Neuropsychologia, 26, 1-12.

Brzeziński J. (1996), Metodologia badań psychologicznych. Warszawa: PWN.

Cattaneo Z., Vecchi T., Cornoldi C., Mammarella I., Bonino D., Riccardi E., Pietrini P. (2008). Imagery and spatial processes in blind and visual impairment. Neuroscience and Biobehavioral Reviews, 32, 1346-1360.

Dulin D., Hatwell Y. (2006). The effects of visual experience and training in raised-line materials on the mental spatial imagery of blind persons. Journal of Visual Impairment and Blindness, $100,414-424$.

Francuz P., Mackiewicz R. (2005). Liczby nie wiedza, skąd pochodza. Lublin: Wydawnictwo KUL.

Heller M. A. (2006). Picture perception and spatial cognition in visually impaired people. [W:] M. A. Heller, S. Ballesteros (red.), Touch and Blindness. Psychology and Neuroscience (s. 49-71). Mahwah: Lawrence Erlbaum Associates.

Heller M. A., Brackett D. D., Scroggs E., Steffen H., Heatherly K., Salik S. (2002). Tangible pictures: Viewpoint effects and linear perspective in visually impaired people. Perception, 31, $747-769$.

Jagodzińska M. (2003). Rozwój pamięci w dzieciństwie. Gdańsk: Gdańskie Wydawnictwo Psychologiczne.

Kennedy J. M. (1993). Drawing and the Blind: Pictures to Touch. New Haven: Yale University Press.

Kennedy J. M., Juricevic I. (2003). Haptics and projection: Drawings by Tracy, a blind adult. Percetion, 32, 1059-1071.

Kennedy J. M., Juricevic I. (2006). Form, projection and pictures for the blind. [W:] M. A. Heller, S. Ballesteros (red.), Touch and Blindness. Psychology and Neuroscience (s. 73-93). Mahwah: Lawrence Erlbaum Associates. 
Marmor G. S., Zaback L. A. (1976). Mental rotation by the blind: Does mental rotation depend on visual imagery? Journal of Experimental Psychology: Human Perception and Performance, $2,515-521$.

Młodkowski J. (1998). Aktywność wizualna człowieka. Warszawa: Wydawnictwo Naukowe PWN.

Smith M., Franz E. A., Joy S. M., Whitehead K. (2005). Superior performance of blind compared with sighted individuals on bimanual estimations of object size. Psychological Science, 16, $11-14$.

Szubielska M. (2009). The role of visual experience on the strategies of blind and sighted individuals in mental imagery. Oslo: XI European Congress of Psychology, 7-10 July.

Szubielska M. (2013). Skaning, rotacja i majoryzacja figur w wyobraźni. Badania porównawcze osób niewidomych $i$ widzących. Niepublikowany raport $\mathrm{z}$ badań finansowanych $\mathrm{z}$ grantu MNiSW (nr N N106 064235), Lublin.

Szubielska M., Marek B. (2012). Comprehension of tactile graphics by school-aged children with severe visual impairment: The role of tactile perception and spatial imagery. [W:] $15^{\text {th }}$ European Conference on Developmental Psychology (s. 121-130). Bologna: Medimond Publisher.

Toroj M., Szubielska M. (2011). Prior visual experience, and perception and memory of shape in people with total blindness. British Journal of Visual Impairment, 29, 60-81.

Vanlierde A., Wanet-Defalque M.-C. (2004). Abilities and strategies of blind and sighted subjects in visuo-spatial imagery. Acta Psychologica, 116, 205-222.

Vanlierde A., Wanet-Defalque M.-C. (2005). The role of visual experience in mental imagery. Journal of Visual Impairment and Blindness, 3, 165-178.

\title{
Magdalena Szubielska, BogusŁaW MareK
}

\section{THE ROLE OF VISUAL EXPERIENCE IN MENTAL MAJORIZATION AND MINORIZATION. REPORT ON A STUDY ON BLIND LEARNERS}

\begin{abstract}
It has been confirmed that the ability to visualize images, attributed to memories of visual experience, helps blind persons perform a wide range of tasks engaging spatial imagery. Two experiments involving totally blind students tested the importance of the ability to visualize images for accuracy of mental operation of enlarging or reducing the size of objects. It was hypothesized that congenitally blind persons commit a greater error than those retaining visual memory (H1) in enlarging objects (Experiment 1: mental majorization), and (H2) in reducing the size of objects imagined to be moving away (Experiment 2: mental minorization). The first hypothesis was partly confirmed. Students blind since birth showed a tendency to overestimate the size of objects which they explored manually and then mentally enlarged than those with no memories of visual experience. The second hypothesis was not confirmed - both groups made comparable mental resizing of objects imagined to be moving away.
\end{abstract}

Keywords: mental majorization, mental minorization, blind students, visualization, spatial imagery. 